\title{
Revitalization of Arabic Education in the Nigerian Tertiary Institution of Learning in Yoruba Land: Entrepreneurship Education a Panacea
}

\author{
Mr. Shittu Morufudeen Adeniyi \\ Faculty of Education and Human Development, Universiti Pendidikan Sultan Idris, Malaysia \\ Dr. Ibrahim Ali Allafiajiy \\ International Islamic University, Malaysia \\ Dr. Ahmad Tijani Surajudeen \\ Sokoto State University, Sokoto, Nigeria
}

\begin{abstract}
The state of Arabic education in Nigerian Tertiary Institutions needs urgent revival, especially in Yoruba speaking states. Most of Arabic graduates seeking for employment are denied. This paper therefore focuses on the overall benefits these graduates can serve to themselves, individual, community, and government in general, if the benefits therein are taped. The present study embarked on the theory of illuminative evaluation (TIE) as the theoretical framework and entrepreneurial skills as the conceptual model. Basically, the study used qualitative method research design by carrying out the interview to seek the opinions of some stakeholders such as lecturers of Arabic language, students, parents, graduates of Arabic language that are working under company or governmental as well as non-governmental organization on the current practice, and implementation of language curriculum in Nigeria. The results showed the importance of blending the curriculum of Arabic language together with the entrepreneurial skills in order to create job opportunities and competencies for the students of Arabic language in the work-environment in the country.
\end{abstract}

Keywords: revitalization, Arabic education, entrepreneurship education, Yoruba land

\section{Introduction}

The old Arabic adage در كما تدورالزمان "keep pace with the development" poses challenges to Arabic curriculum planners and teachers to be dynamic in their training and teaching activities. Hence, Arabic teaching methodology ought to be changed from time to time. It does not have to be static, it can be student centred, class centred, or societal/community centred (Shittu, Yusuf, Sabri, \& Ajape, 2004).

An insight into the future of Arabic Studies in Nigeria Institutions of Higher Learning presently, especially

\footnotetext{
Mr. Shittu Morufudeen Adeniyi, Ph.D. student, (Arabic Curriculum Studies) Faculty of Education and Human Development, Universiti Pendidikan Sultan Idris, Malaysia. Lecturer, Department of Arabic Studies, Michael Otedola College of Primary Education, Noforija, Epe, Lagos State, Nigeria.

Dr. Ibrahim Ali Allafiajiy, B.A. (Arabic \& Islamic Dawah) Madina, M.A. \& Ph.D. (Education Psychology), International Islamic University, Malaysia.

Dr. Ahmad Tijani Surajudeen, Sokoto State University, Sokoto, Nigeria.
} 
those in Yoruba speaking lands would envisage decline in the nearest future (Sanni, 2012). If one looks at the laudable achievements of the Arabic leaders (past and present) which they put together to sustain the language, one would not allow it to decline. They have tried a lot "that is what they could reach of knowledge" (Quran 53) as they have done what are expecting of them.

The challenges posed to the present younger scholars are that they should start from where the leaders stopped. Among others areas that need focus is Arabic Entrepreneurship Education for creating job opportunities.

By the general public, there is a negative perception ascribed to Arabic language as a language of religion rather than being one of the foreign languages like French in Nigeria. Lackadaisical attitude of government to consider Arabic language as foreign language in the country is influenced by the sensitivity of religion as well as religious rivalry between Muslims and Christians.

Undeniably, it can be asserted that the reason for the narrowed job opportunities for the graduates of Arabic language is as a result of the lack of essential skills such as: entrepreneurial skill as it is noted that entrepreneurial skill is very essential for students to be excelled in the 21 st century.

Reiteratively, the curriculum of Arabic language does not cater for the need of market; curriculum design and its implementation do not give importance and priority to the marketability of the course as a foreign language in the country.

The paper is an attempt to find the way Arabic curriculum could be packaged with entrepreneurial skill to ensure the employability of Arabic learners in today's world market force in Yoruba lands. It is believed that this attempt could be achievable as "nothing was not left without discuss in the Arabic Holy Book" (Quran 6, 38).

\section{Literature Review}

\section{Historical Survey of Arabic Language in Nigeria}

Al-ilori (1978) asserted that the emergency of Arabic language in Nigeria was dated back to the 8th century when it entered with its culture and civilization into several spheres of Nigeria society in the area of religion, language, culture, and commerce. According to Abdelali (2003), Islam along with its language penetrated the kingdom of Kanem-Borno situated in modern Chad, turning it into Muslim kingdom in the 15th century AH. He went further quoting Ali Abu Bakr (n.d.), speaking about Arabic under Ottoman reign, established by sheik Othman Bin Foudi in the 13th century Hegira (9th century AC) a Scholar from Nigeria saying: "Arabic was the only language in which were drawn up all the reports of the empire in the nineteenth century" (pp. 223-224).

Abdelali added that, despite colonial pressure, the courts in the Wilaya Kano use Arabic exclusively until 1960. Ayuba (2012) suggested that Arabic had established itself in Nigeria as the language of administration, literacy, education, history, and legislation before the arrival of colonial masters. This assertion was also attained to by Gbadamosi (1978), Galandanci-shaykh (1982), Yahya (1986), and Lawal (2007) with the spreading of Islam in this region, which later developed in the modern times into several states. Arabic became the language of writing, reading, and communication among these states in various fields. To buttress this, 115 books were written by Sheik Othman Bin Foudi, his brother, Abdullah Bin Foudi, known otherwise as the "Master" wrote more than 200 books, and Sultan Muhammed Bello authored about 100 books all in Arabic.

In Ibadan and Ede, documents written in Arabic script were found in the palace of both Olubadan and 
Timi of Ede (Lawal, 2006). The arrival of British colonization in 19th century and introduction of English as an official language in Nigeria abate the status of Arabic language in the country (Fafunwa, 1979, as cited in Ajape, 2014). The activities of European Christian missionaries and the introduction of western education become language of employment in Nigeria. As a result, teaching and learning of Arabic language were given little attention. Al-ilori (1978) as cited in Ajape (2014) illustrated the impact of the colonization on Arabic studies thus: "When the British Colonial Masters came, they were highly furious to meet Islam in West Africa not only as a religion but also as a powerful Government and an established nation" (p. 8).

He then reported their negative reaction thus: They changed Arabic civilization with European civilization, replaced Islamic law with common law, sent out the Muslim jurists, replaced with lawyers and humiliated Arabic learners, and replaced with English learners (Al-ilori, 1978, p. 149).

In spite of this declining, Arabic scholars continue learning Arabic by establishing private Arabic schools in various parts of the country. Of these efforts are Markaz at ta'lim al 'arabi founded by Late Shaykh Adam Abdullahi Al-ilori in 1950 at Abeokuta and moved to its permanent site Agege, Lagos, Nigeria in 1952. Daru d Da'wah wal irshad founded by Shaykh Mustapha Zaglul as Sanusi in 1970 at Mushin moved to its permanent site Isolo, Lagos, Nigeria in 1980. Karachi Memorial Arabic Secondary School, Ibadan, Oyo Nigeria founded by late Shaykh Narir Alhaji Muhammed Thani Karasi and Alhaji Issa Magaji in 1945. Arabic Institute (MA'HAD) of Nigeria, Ibadan, Oyo, Nigeria, founded by late Shaykh Murithad Abdul Salam in 1958. Islamic preaching School, Ibadan, Oyo, Nigeria, (Ad Da'wah), founded by late Shaykh Ballo Alli Adelani in 1974 and host of other Arabic schools in Oyo, Kwara, Osun, Ogun, Ekiti, and Ondo States. Islamic Organizations in the Country such as An sar ud deen society of Nigeria, Nasfat, Anwar Islam, Nawair deen, Zumratul Islamiyyah, and Jama'atul Islamiyyah established modern Arabic schools. It was the products of these citadels of learning serving private and public Higher Institutions where Arabic is been taken as a course of study till date. The graduates of this language are found throughout public and private sector within and outside the country, mostly for teaching and lecturing (Arabic Language and Literature). Some are found in other fields with additional qualifications.

\section{The Brief History of Entrepreneurship in Nigeria and Its Benefit}

Entrepreneurship is more than simply business. According to Hupalo (2007) as cited in Aishat (2013), entrepreneurship is the recognition and pursuit of opportunity without regard to the resources one currently controls, with confidence that one can succeed, with the flexibility to change course as necessary, and with the will to rebound from setbacks. Another definition of entrepreneurship is that this concept involves risk and responsibility in designing and implementing a business strategy or starting a business (Investor words, 2006).

Aishat (2013) further stated that, without entrepreneurship there is no life, and without life, there is no living. Man continues to live when his four basic needs are met, namely, food, drink, clothing, and shelter. These basic needs cannot be fulfilled without the existence of entrepreneurship. Entrepreneurship constitutes a vital engine in the economic growth and development of nations including Nigeria because it helps in the stimulation of indigenous entrepreneurs, leads to the transformation of traditional industry, creates employment opportunities, generates incomes locally and externally, and contributes to regional activity and co-operation (Thematic, 2013).

Studies have demonstrated that, Nigeria is a rich country in terms of human and natural resources; notwithstanding, the country is still one of the poorest countries in the world and has one of the highest rates of 
youth unemployment in sub-Sahara Africa (Salami, 2011).

Entrepreneurship exists in Nigeria before the advent of the British Colonial Masters but it becomes significant only after the Nigerian civil war (Thaddeus, 2012). Historically, the landmark of Arabic in Nigeria is through commerce and economic improvement (Lawal, 2006).

Studies have shown the new trend of entrepreneurship in Nigeria, for instance, the presidency has directed all Nigerian Higher Education Institutions to include entrepreneurship education (Ed) as a compulsory course for all students with effect from 2007-2008 academic session. It was reported that one of the objective of implementing entrepreneurship is to consider self-employment as a viable option upon graduation of the students from their institutions. The interim results of the conducted studies show that, the government initiatives have improved productivity and provided sustained local economic development for the Nigerian people (Aliu, Hamitle, \& Ibe, 2008). In light of entrepreneurship practices in Nigeria, the Centre for Entrepreneurship and Development Research, University of Nigeria Nsukka had organized a series of lectures on the topic by drawing speakers from leading Nigerian entrepreneurs to share their professional ideas and practices, challenges and way forward so as to encourage people to have their own business or to support those that have had one business doing.

\section{Objectives of the Study}

The objective of this study is to explore the opinions of stakeholders (lecturers, students, and parents) on curriculum of Arabic in providing entrepreneurship skills for the Arabic graduates.

\section{Research Questions}

The question below is answered by the present study:

What is the perception of the stakeholders (lecturers, students, and parents) towards curriculum of Arabic in providing entrepreneurship skills for the Arabic graduates?

\section{Theoretical Framework}

Illuminative evaluation theory propounded by Parlett and Hamilton (1972) consists of instructional strategy and learning milieu. The theory states that, in the instructional strategy, teachers play an important role in the implementation of the curriculum of a particular educational programme which requires proper planning and preparation. Similarly, in learning milieu, instructional materials, mental preparation, readiness, and conducive environment that make the learning possible, enable the teachers and the students to work together in order to achieve a common goal.

\section{Conceptual Model}

In the conceptual framework, entrepreneurial skill is one of the essential skills required of the students of tertiary institutions at the work place after graduation in order to properly address the challenges faced by Arabic students in the work environment which may go beyond the scope of their disciplines.

When the learners possess essential knowledge, skills, and abilities such as entrepreneurial skills then they will have competence to perform necessary tasks assigned in the work environment (Elizabeth et al, 2002). Therefore, it can be inferred that, the curriculum can be enhanced towards the acquisition of the skills in the learning environment, however, the competence to apply the acquired skills beyond the learning environment. 
This means, if entrepreneurship is incorporated into the curriculum of Arabic language in higher institutions in Nigeria. As a result, many of the graduates would not capitalize on the government jobs, as a result they will solve alarming rate of unemployment in the country.

The conceptual model posits that curriculum of Arabic language must be designed in such a way that job opportunities will be provided for the graduates of the course in tertiary institutions and in the work environment and they will be provided with the soft skills that will enable them excel in their career life. Figure 1 shows the conceptual model.

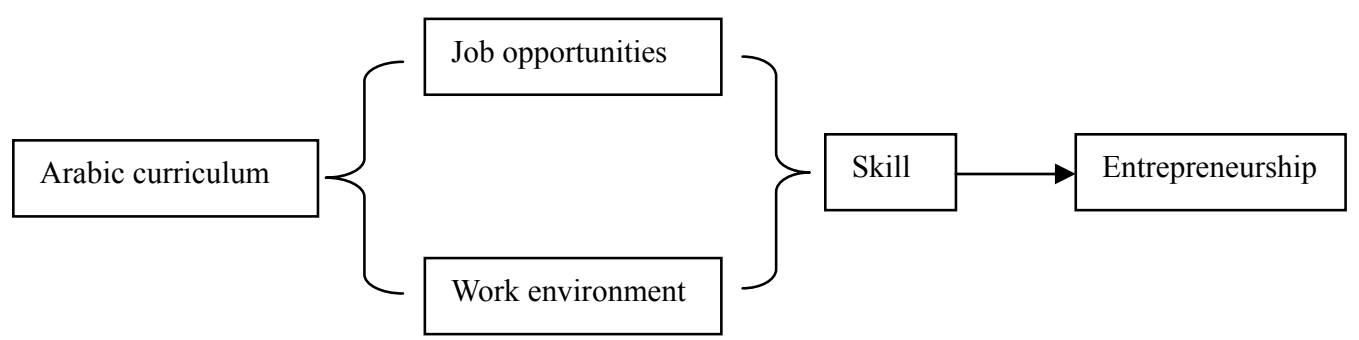

Figure 1. A conceptual model of the study towards effectiveness of Arabic curriculum in fostering students' skills in work-environment.

\section{Method}

This study was a qualitative study. The researchers interviewed five Arabists who were selected purposively at the five Nigeria institution of higher learning, namely, University of Ilorin, University of Lagos, Osun State College of Education, Ilesha, Federal College of Education (Special), Oyo, Arabic Program Officer, National Commission for Colleges of Education (NCCE), and National Open University. The Arabic experts were selected for having rich information about the challenges facing Arabic and its learners in Yoruba Lands, Nigeria. Each interview was conducted for 30 minutes at the convenient time of the interviewees at the said universities.

The first interviewee is a professor of Arabic and Islamic Studies and formal vice chancellor. He was interviewed at the National Open University in Lagos on August 12, 2014 at 4 pm. The second interviewee is also a professor of Arabic and Islamic Studies Education at the University of Lagos. He was interviewed on August 12, 2014 at 6 pm. The third interviewee is a Dr., a chief lecturer at the Osun State, College of Education, Ilesha. The interviewed was carried out in his office at the said college at $12 \mathrm{pm}$ on August 25, 2014. The fourth interviewee is a chief lecturer at the Federal College of Education (Special), Oyo State. The interview was carried out for him on August 28, 2014 at 9 am at the same College. The fifth interviewee is a Dr., a tutor at Dar Dawah, Isolo, Lagos and Al-Furqan Islamic Organization. The interview conducted for him was carried out on August 27, 2014, at 12 pm in Dar Dawah. The interview was transcribed for meaningful themes. The interview question related to the research question raised is as follows:

The interview question asked is: In what ways do you think Arabic curriculum could be designed towards providing entrepreneurial skills for Arabic graduates?

\section{Discussion of Findings}

Based on the transcription as shown in Table 1 (see the Appendix), the following major themes that emerged from the interview session were discussed.

Entrepreneurial skill is lifeblood of human being. On this skill stands all lives of human being as Aishat 
(2013) expressed that, without entrepreneurship, living becomes difficult. With regard to this, all the five interviewees agreed to the fact that, entrepreneurship is needed for the growth of Arabic language in Nigeria. They all agreed with the following two themes.

\section{Translation}

Translation is a one of the lucrative jobs. It earns a good living. This job is recognized by almost all the informants. For example, the first interviewee when asked he said "Arabic curriculum should be tailored towards translation...".

Other interviewees agreed with this viewpoint when interrogated. The results of this study showed that Arabic learners should be multi-lingual so as to carry out the translation task as expected of them. Translation should be encouraged among those learners even to the level of becoming news broadcasters as suggested by the interviewees.

\section{Vocational Job}

Vocational job is of various types. It can be tailoring, catering service, calligraphy, video editing, computer, or any handiwork. In this study, all the five interviewees mentioned different kinds of vocational jobs that can be suitable for Arabic learners. According to the interview carried out as in Table 1 (see the Appendix), one of the interviewees conceded to the significance of having additional job will help create job for Arabic students in Nigeria when asked they responded, "I suggest we can do is to teach the Arabic graduates in South West works such as tailoring and bricklaying"; other said, "Students can be taught... lettering...".

\section{Suggestions}

From the aforementioned themes, the researchers suggest the following to create job opportunities for the Arabic graduates in Nigeria.

(1) Government's support for the Arabic students as its support for English learners in the country;

(2) The amendment of the Arabic curriculum to meet the demand of market force so that, its learners can be employable in the world;

(3) The seriousness of the Arabic students themselves in diversifying learning such as learning ICT (Information Communication Technology) and additional handiwork that will help them before and after graduation;

(4) Bridging the gap between the Arabic curriculum and the world of work so that, Arabic students can also afford standard of living as their counterparts;

(5) Willingness of our tertiary institutions to teach courses that are viable for Arabic students not only teaching for the purpose of teaching, so that, the Arabic students would not become idle or learning Arabic for the purpose of knowing only but to also live well in this world.

\section{Conclusion}

This paper concludes that, Arabic would have been a language acceptable by the Nigerians in regardless of religion if packaged well. We observed that, Arabic curriculum needs to be tailored towards the creation of entrepreneurial skills to ensure that Arabic graduates grab the advantages of being employed as their English counterparts. We are of the opinion, that, the lecturers in our tertiary institutions in Yoruba land as well as 
Madaris proprietors should come together to look to areas where Arabic will benefit the Arabic graduates. To put it differently, Arabic curriculum planners are encouraged to learn from other countries such as Malaysia where Arabic graduates get employed in any government sectors. We found in terms of illuminative theory utilized in this study that, both Arabic teachers and students should come together to form an avenue for discussing a way to make Arabic a language of employment first, or a way of merging it into with entrepreneurial skills such as those mentioned by the interviewees.

\section{References}

Abdelali, E. Q. (2003). Arabic language in Sub-Sahara Africa: Past, present \& future. Islam: ISESCO.

Aishaa, A. (2013). State of entrepreneurship in Nigeria, its practices, challenges and way forward. Malaysia: Insaniah College University.

Ajape, K. O. (2014). Evaluation of Arabic language curriculum in selected universities in Nigeria \& its relevance to the national policy on education (Ph.D. thesis, Institute Of Education, IIUM).

Al-ilori, A. A. (1978). al Islam fi Naijiriya wa Shaykh 'uthman bn Fodio al Fulani, Markaz (Islam in Nigeria and Shaykh 'Uthman Son of Fodio from Fulani Tribe). Lagos, Nigeria: Agege.

Aliu, S., Hamitle, C., \& Ibe, G. (2008). Recent trends in entrepreneurship education in Nigeria: Prospects and challenges. Retrieved from http://www.isbe.org.uk/Dr.SolaAliu08

Alli, A. B. (n.d.). Arabic culture in Nigeria. Al-Lisan, Journal of the Nigeria Association of Teachers of Arabic in Colleges of Education and Allied Institutions (NATACEDA), Ilorin, Nigeria.

Ayuba, M. A. (2012). The Arabic language: Its relevance to Nigerian development. European Scientific Journal, 8(26), 190.

Hupalo, P. (2007). Thinking like an entrepreneur. Retrieved from http://www.thinkinglike.com/AboutUs.html

Lawal, A. I. (2006). The relevance of Arabic language to Nigeria. Religious Forum Academia, II(1), 20.

Salami, C. G. E. (2011). Entrepreneurial interventionism and challenges of youth unemployment in Nigeria. Global Journal of Management and Business Research, 11(7). USA: Global Journals Inc..

Sanni \& CO. (2012). Rationalization of academic programs: The case of Arabic and Islamic studies. LASU Senate.

Shittu, M. A., Yusuf, M., Sabri, M. S., \& Ajape, K. O. (2004). Preparing Arabic students for future challenges: Need for curriculum development. Ipoh: UPSI.

Thaddeus, E. (2012). Perspectives: Entrepreneurship development and growth of enterprises in Nigeria. Journal of Entrepreneurial Practice Review, 2(2).

Thematic, F. (2013). Entrepreneurship development in Nigeria: Its problems and prospects. Retrieved from http://articlesng.com/entrepreneurship-development-nigeria-problem/prospect 
Appendix

Transcription Table 1

S/N Interviewer (I)

In what ways do you think Arabic

1 curriculum could be designed towards providing entrepreneurial skills for Arabic graduates?

In what ways do you think Arabic

2 curriculum could be designed towards providing entrepreneurial skills for Arabic graduates?

In what ways do you think Arabic

3 curriculum could be designed towards providing entrepreneurial skills for Arabic graduates?

In what ways do you think Arabic

4 curriculum could be designed towards providing entrepreneurial skills for Arabic graduates?

In what ways do you think Arabic curriculum could be designed towards providing entrepreneurial skills for Arabic graduates?
Interviewee (IN)

...I think, this curriculum should be improved, to be dynamic, meet students' need, community, and global prospect.

Arabic curriculum should be tailored towards translation, art, contemporary issues, current terminologies, literature, conflict issues, ICT, Morphological technicalities. .

Hahaha, I have been teaching Arabic and Islamic studies since 1951 to date.

Curriculum of Arabic did not cater for job opportunity because it was taught and learnt for religious purpose. Teaching and learning Arabic in Nigeria is founded on understanding Qur'an and Hadith.

I see that, curriculum of Arabic language needs to create sound translators in news broadcast, translators in conferences.

Arabic is still facing problem in Nigeria because government did not create an enabling environment for the language. What I suggest we can do is to teach the Arabic graduates in South West works such as tailoring and bricklaying.

I think, the Arabic curriculum is still ok, but, the Government does not help in delivering it.

Students can be taught how to be a clergy, indigenous Prophetic medicine, design art work, lettering, beautification of religious centers, translation, and Yoruba cultural heritage.

I see because Arabic is not duly not recognized as expected in Yoruba land, the Arabic students do not benefit from that language.

Arabic curriculum should be uniformed; it should be developed in a way that, it can create vocational job, act of buying and selling and whatsoever. 